\title{
Opportunities to analyse pupils' learning within coursework on campus: A remaining challenge in teacher education
}

This is the accepted version, accepted for publication in European Journal of Teacher Education see https://doi.org/10.1080/02619768.2018.1448783 for the published version

Inga Staal Jenset ${ }^{\mathrm{a}^{*}}$

${ }^{a}$ University of Oslo, Department of Teacher Education and School Research Postboks 1099 Blindern

0317 Oslo, Norway.

i.s.jenset@ils.uio.no

Esther Tamara Canrinus ${ }^{\mathrm{a}}$

e.t.canrinus@ils.uio.no

Kirsti Klette ${ }^{\mathrm{a}}$

kirsti.klette@ils.uio.no

Karen Hammerness ${ }^{\mathrm{b}}$

American Museum of Natural History

Central Park West at $79^{\text {th }}$ Street

New York, NY 10024

USA

khammerness@amnh.org

*corresponding author 
This work was supported by the Norwegian Research Council under Grant number 212289.

\begin{abstract}
To support pupils' learning, teachers must understand what and how their pupils have learned, and teacher education should teach candidates how to do this. This article reports on survey data $(n=270)$ from three programmes and observation data $(N=$ 104 hours) from six programmes, located in Norway, Finland and the US. It examines the candidates' opportunities to analyse pupils' learning within their coursework. The authors argue that such opportunities might constitute profound possibilities to examine the complexity of teaching and learning. However, the study finds that the candidates have few opportunities to analyse pupils learning and that the full potential of these opportunities is unrealized. The authors argue for increased, specific attention to pupils' learning within teacher education coursework, through a pedagogy of teacher education informed by existing research on how to elicit pupils' learning.
\end{abstract}




\section{Introduction}

The growing body of feedback literature has generated increased attention on the role of feedback for learning (i.e., Hattie and Timperley 2007; Wiliam 2010). Teacher candidates should have opportunities to familiarise themselves with this literature and learn about assessment and feedback theory. This paper, however, investigates the extent to which candidates receive opportunities to develop knowledge and skills to enact the practices of assessment and giving feedback in order to thoroughly understand what and how pupils have learned (Shepard et al. 2005). Teaching and learning are complex and situated practices (Bruner 2010; Chaiklin and Lave 1993; Grossman et al. 2009; Kennedy 1999; Lampert et al. 2013; Shulman 1987). Therefore, being able to analyse pupils' learning goes beyond grading and evaluation of pupils' work (Allen 1998a). As pupils learn by connecting to their prior knowledge, teachers can build upon that knowledge and adjust their instructional practices accordingly (Allen 1998a; Driver 1989; Windschitl et al. 2012). Some scholars have argued that this is the core of what a teacher needs to know and be able to do (Boyd et al. 2009; Hiebert et al. 2007; Little et al. 2003; Windschitl et al. 2012).

Still, adjusting teaching to pupils' needs is difficult even for experienced teachers (Maulana, Helms-Lorenz, and van de Grift 2015), and teacher preparation plays a vital role in this respect. Fieldwork allows candidates to come close to pupils' learning, and substantial evidence has indicated that such experiences are critical for candidates' future success in the classroom (e.g., Darling-Hammond et al. 2005). However, Britzman (2003) argued that field placement alone is not sufficient, rather, candidates need both coursework and fieldwork to learn ambitious teaching practices (i.e., practices that are socially and intelletually more ambitious than the current norm and push pupils to higher order learning goals, see for instance Lampert et al. [2013]). 
Similarly, Darling-Hammond (2017) argued that the combination of thoughtful coursework design and high-quality fieldwork is a promising strategy for improving teacher education. Thus, the campus site of teacher education plays a vital role in providing opportunities to enact distinct teaching practices, such as analysis of pupils' learning (cf. Ball and Cohen 1999; Kennedy 1999).

This study is part of a larger project investigating coherence and the enactment of teaching practices in teacher preparation programmes (see Hammerness \& Klette 2015). One significant finding was that candidates on average perceived that they had relatively few opportunities to enact practices related to analysing pupils' learning (cf. Canrinus, Bergem, Klette, \& Hammerness, under review). This finding, together with the importance for understanding pupils' learning stressed in the literature, prompted this study in which we examine the following questions: (a) How do candidates perceive the opportunities they have to analyse pupils' learning within their coursework on campus? (b) What characterises these opportunities when observed by external observers?

\section{Theoretical framing}

Teaching and learning are complex and situated practices (e.g., Chaiklin and Lave 1993). Several efforts have been made to identify the structure of teachers' knowledge base (e.g., Blömeke, Gustafsson and Shavelson 2015; Shulman 1987), and descriptions of how teachers learn to teach (e.g., Shepard et al. 2005; Kennedy 1999). Such frameworks illustrate the complexity of all aspects a teacher needs to take into account before making a decision in the contextualized classroom. For the purposes of this paper, it is important to emphasize that this complexity relates to subject content knowledge, but also the teachers' knowledge about the pupils and their characteristics 
(Shulman 1987). Pupils construct their own knowledge individually or with others, and connect to their prior knowledge (Bruner 2010; Chaiklin and Lave 1993; Grossman et al. 2009; Lampert et al. 2013). In order to adapt their teaching to the pupils, teachers need to fit their teaching to the abilitites, skills, misconceptions etc. relevant for the age group or the specific group of pupils (Shulman 1987). Teachers, then, need skills and strategies for retrieving this information. Indeed, this has been emphasized, particularly in science education, since the 1970s, with a focus on the importance of 'making thinking visible' (Driver 1989; Duit and Treagust 2003; Ritchhart, Church, and Morrison 2011). This work is our starting point when conceptualising how candidates can analyse pupils' learning by obtaining evidence, or traces, of learning (Driver 1989; Duit and Treagust 2003).

Opportunities to learn about pupils' learning.

Perhaps the most direct way to obtain this evidence of learning, is the inclusion of authentic pupils' work from K-12 schools. Examining pupils' work or assignments allows candidates to practice activities related to understanding pupils' learning (Allen 1998a; Ball and Cohen 1999; Kazemi and Franke 2004). Ball and Cohen (1999) called for the inclusion of $\mathrm{K}-12$ artefacts as a curriculum for teacher education. Examining pupils' work has many purposes, ranging from getting to know an individual pupil as a learner, to establishing standards for performance (Allen 1998a). It also creates a professional community for teachers to scrutinize their own pupils' work, and thus their own planning, teaching and grading (Allen 1998b).

Kazemi and Franke (2004) showed that understanding teachers' interactions with pupils was equally important as investigating pupils' work. Scholars have suggested teachers make diverse 'talking moves' to make pupils' learning visible, 
including posing open-ended tasks or questions; using pauses, re-voicing, and rephrasing; pressing for evidence-based explanations; or posing alternative examples (Mercer and Dawes 2014; Ritchhart et al. 2011; Windschitl et al. 2012). Teachers' use of these practices may be captured through the use of video as an instructional tool in teacher education (Gaudin and Chaliès 2015; Hatch and Grossman 2009). Although these practices are not direct evidence of pupils' learning, they represent instructional strategies teachers could use to scaffold learning. As such, they are important for candidates to recognize when learning to analyse pupils' learning (Gaudin and Chaliès 2015; Kazemi and Franke, 2004).

Summarizing, the inclusion of pupils' work and videos of classroom interactions represent important instructional practices in teacher education in order for candidates to learn to analyse pupils' learning (see also Figure 1). However, research has shown that using artefacts and video must be scaffolded by the teacher educator (Kazemi and Franke 2004; Little 2004).

\section{Scaffolding learning about pupils' learning}

Researchers point to a variety of specific startegies teacher educators could use while working with artefacts or videos of teaching. For instance, they could scaffold candidates by providing opportunities for candidates to learn how to look for evidence of learning in the artefacts they work with (Shepard et al. 2005; Windschitl et al. 2012). Further, the teacher educator could use scaffolds to guide the candidates to discover patterns of error, misconceptions, or common errors made by pupils (Boyd et al. 2009; Kazemi and Franke 2004). Engaging in such practices requires strong subject content knowledge (Shulman 1986), and the teacher educator plays a vital role in supporting the candidates in identifying these subject specific aspects of the pupils' work. A variety of 
tools for doing so do exists (Allen and Blythe 2004; Allen, Ort, and Schmidt 2009; Blythe, Allen and Powell 2008; Cushman 1996). The "Tuning protocol" is one instrument that provides a detailed structure for how to look at pupils' work, that could be introduced in teacher education. One teacher (candidate) presents samples of his or her own pupils' work; others ask clarifying questions and provide feedback to the pupils' work; and finally, the presenting candidate responds to the feedback given (Allen 1998a; for an overview of additional protocols, see McDonald, Mohr, Dichter and McDonald 2013).

The teacher educator could also scaffold the candidates by ponting to strategies teachers use to elicit pupils' learning and make thinking visible, as reffered in the literature above (e.g., Ritchhart et al. 2011). Indeed, a growing body of research examine efforts from teacher educators to support candidates in developing their 'professional vision' or ability to 'notice' (Seidel and Stürmer 2014; Sherin, Jacobs, \& Philipp 2010; Star and Strickland 2008; van Es and Sherin 2002, 2008). Within this body of literature, teacher educators provide opportunities for candidates to look for evidence of pupils learning by watching videos of classroom interactions. They learn to focus their attention on relevant classroom events, and to interpret and analyse these related to the literature (Gaudin and Chaliès 2015; Seidel and Stürmer 2014). Within this body of research, teacher educators have made successful use of multimedia tools with observation prompts (van Es and Sherin 2002) or used specific assignments connected to the observation of video (Star and Strickland 2008), to scaffold their candidates in this process.

Finally, the teacher educator can focus on next instructional steps to help pupils learn, based upon the evidence of learning that has been found (Little et al. 2003; 
Windschitl et al. 2012). More specifically, this could imply that if a candidate has revealed a pupil's error in an assignment on fractions in mathematics, for instance, the teacher educator can point out whether or not this represents a typical misconception The teacher education and candidatete can then engage in a discussion about what other assignments with fractions this pupils could be introduced to, what assignments would be suitable for that level and could contribute to encounter those misconceptions. Figure 1 summarises our conceptual framework, which is further elaborated in the methods section.
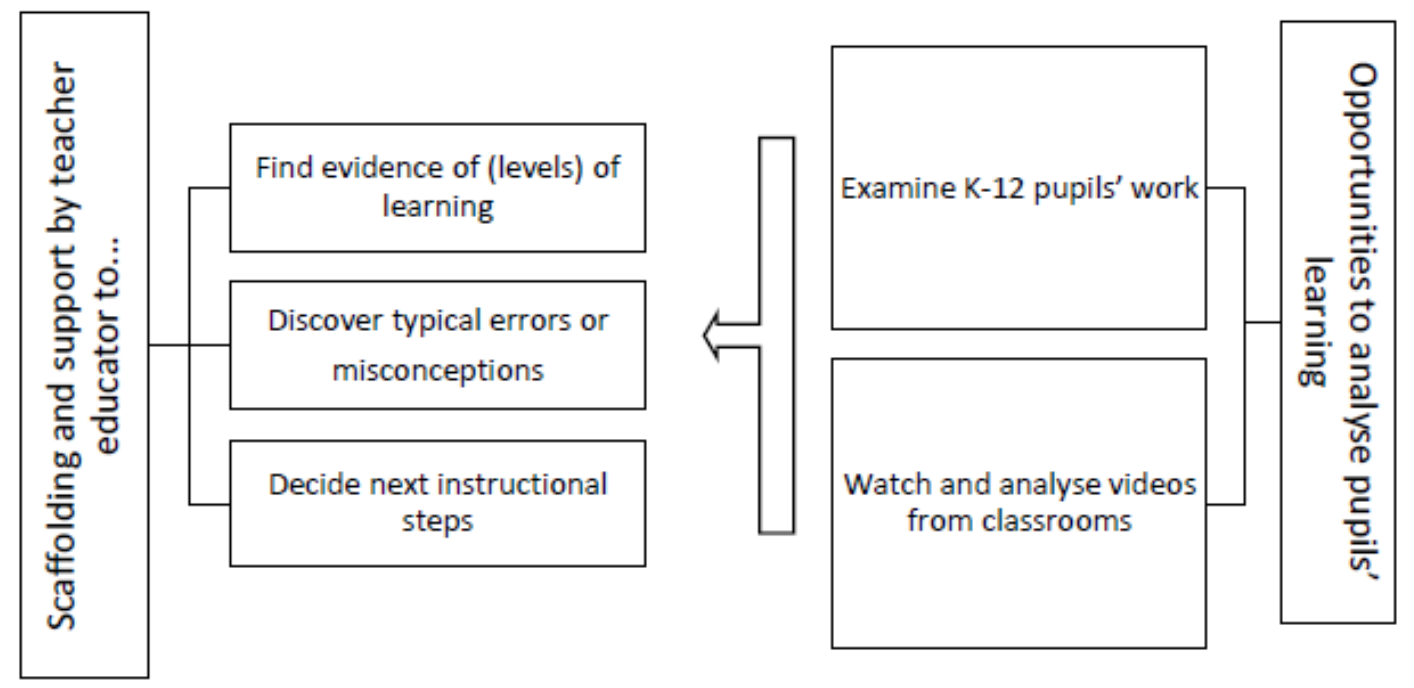

Figure 1. Conceptual framework.

\section{Methods}

We used a multiple-case research design, as this widens our exploration and grounds our findings in a diversity of empirical evidence, which might contribute to a better understanding of the candidates' opportunity to analyse pupils' learning (Eisenhardt \& Graebner, 2007; Stake, 2006). We collected survey data from three teacher education programmes and observation data from six programmes. This section starts with the contextual background of these programmes, followed by the instruments used and a 
description of our analyses.

\section{Sampling}

We sampled six teacher education programmes across three national contexts; Finland, Norway, and California in the United States (US). We chose national contexts offering sufficient variation in teacher education, while being similar enough for comparison (Stake 2006). All programmes have pursued reform efforts, although in various periods. In Finland, large structural changes were implemented in the 1970s, relocating teacher preparation into universities and with teachers in all subject areas and grade levels being obliged to have a master's degree. No major changes have recently been implemented (OECD 2014; Sahlberg 2011). In Norway, substantial resources have lately been invested in teacher quality and education. Teacher preparation is undergoing a substantial reform in the country (Munthe, Malmo, and Rogne 2011; NOKUT 2006). Both Norwegian programmes have worked to ensure a closer connection between fieldwork and coursework (Engelien, Eriksen, and Jakhelln 2015; Wæge and Haugaløkken 2013). Compared to the the Nordic countries, American teacher education is characterised by great diversity (Zeichner 2016). However, both US programmes included are situated in California, and programme California3a systematically redesigned their teacher education programme with the major changes being completed in 2002 to integrate campus courses and field placement experiences. Additionally, the programme aimed to provide candidates with specific opportunities to try out and enact teaching (Hammerness 2006). California3b has a longstanding tradition of continuous programme development based on programme evaluation data (Sloan 2015).

Besides making efforts to be more practice-centred, the programmes were all (a) university-based, (b) preparing teachers at the secondary level (grades 8-13), (c) 
situated in urban areas, (d) perceived as rather selective, with low acceptance rates, and (e) combining coursework with field placement in schools. All programmes were oneyear post-bachelor or post-master programmes, except for the Finnish programmes and Norway2b (See Table 1). In these programmes, we collected data in the year the candidates spent the most time in their field placement to optimise comparability across programmes. 
Table 1. Characteristics of the Sampled Programmes

\begin{tabular}{|c|c|c|c|c|c|c|}
\hline \multirow[t]{2}{*}{ Programme } & \multirow{2}{*}{$\begin{array}{l}\text { Country/ } \\
\text { State }\end{array}$} & \multicolumn{2}{|c|}{ Organisation of Practice } & \multirow{2}{*}{$\begin{array}{l}\text { No. of } \\
\text { Practice in } \\
\text { Hours }\end{array}$} & \multirow{2}{*}{$\begin{array}{l}\text { Acceptance } \\
\text { Rates in \% }\end{array}$} & \multirow{2}{*}{$\begin{array}{l}\text { No. of } \\
\text { Candidates }\end{array}$} \\
\hline & & Intervals & Concurrent & & & \\
\hline 1a & \multirow[t]{2}{*}{ Finland } & $\mathbf{x}$ & & 540 & $10-40^{\mathrm{a}}$ & 410 \\
\hline 1b & & $x$ & & 432 & $89^{b}$ & 40 \\
\hline $2 a$ & \multirow[t]{2}{*}{ Norway } & $x$ & & 480 & 20.5 & 160 \\
\hline $2 b$ & & $\mathbf{x}$ & & 520 & 44 & 220 \\
\hline $3 a$ & \multirow{2}{*}{$\begin{array}{l}\text { California, } \\
\text { US }\end{array}$} & & $x$ & 780 & $-^{c}$ & 72 \\
\hline $3 b$ & & & $\mathbf{x}$ & 1000 & 67 & 29 \\
\hline
\end{tabular}

Notes. ${ }^{a}$ The subject affected the acceptance rate. ${ }^{\mathrm{b}}$ The acceptance rate seems high because there are three different types of teachers in the Finnish education system: subject teachers, class teachers, and special education teachers. Our sample is from subject teachers, and here the acceptance rates are higher than with the other teacher education programmes because these candidates have already gone through one university acceptance process when initiating their major studies. In comparison, the acceptance rates were significantly lower for candidates applying for the class teacher programme (22\%) and for the special education teacher programme (13\%) at Finland $1 \mathrm{~b}$ in 2012. ${ }^{\mathrm{c}}$ This data was not obtained from California3a.

The organisation and amount of fieldwork differed across the programmes, with Californian programmes having more fieldwork than the Nordic programmes. Additionally, the field placement in the Californian programmes occurred concurrently with coursework on campus. Acknowledgeing that the size of the programmes also differed, ranging from 29 candidates at California3b to 410 candidates at Finland1a, we believe that offering opportunities to analyse pupils' learning should be included in all programmes, regardless of programme size. These diverse national contexts and the similarities and differences across these programmes constitute fruitful resources to explore our research questions.

\section{Data sources}

Survey

The survey data stems from a paper-and-pencil survey included in a greater study on 
candidates' possibilities to enact practice in their preparation programme (see Hammerness \& Klette 2015). Candidates revealed they had few opportunities to analyse pupils' learning; they rated three items regarding these opportunities low when compared to other items on opportunities to enact practice (see Figure 2). These items were the candidates' opportunities to: (a) examine samples of K-12 pupils' work (item 1C), (b) examine transcripts of real K-12 classroom talk or pupils' discussions (item $1 \mathrm{G})$, and (c) watch or analyse videos of classroom teaching (item $1 \mathrm{H}$ ). Figure 2 shows the mean score for all items across the included programmes. Additionally, the figure shows the relatively low score of the selected items compared to items measuring other issues, such as candidates' perceived opportunities to plan for teaching in item 1A (see Canrinus, Bergem, Klette, \& Hammerness, under review). The extensiveness of the opportunities was rated on a scale of 1 (None) to 4 (Extensive opportunity). 


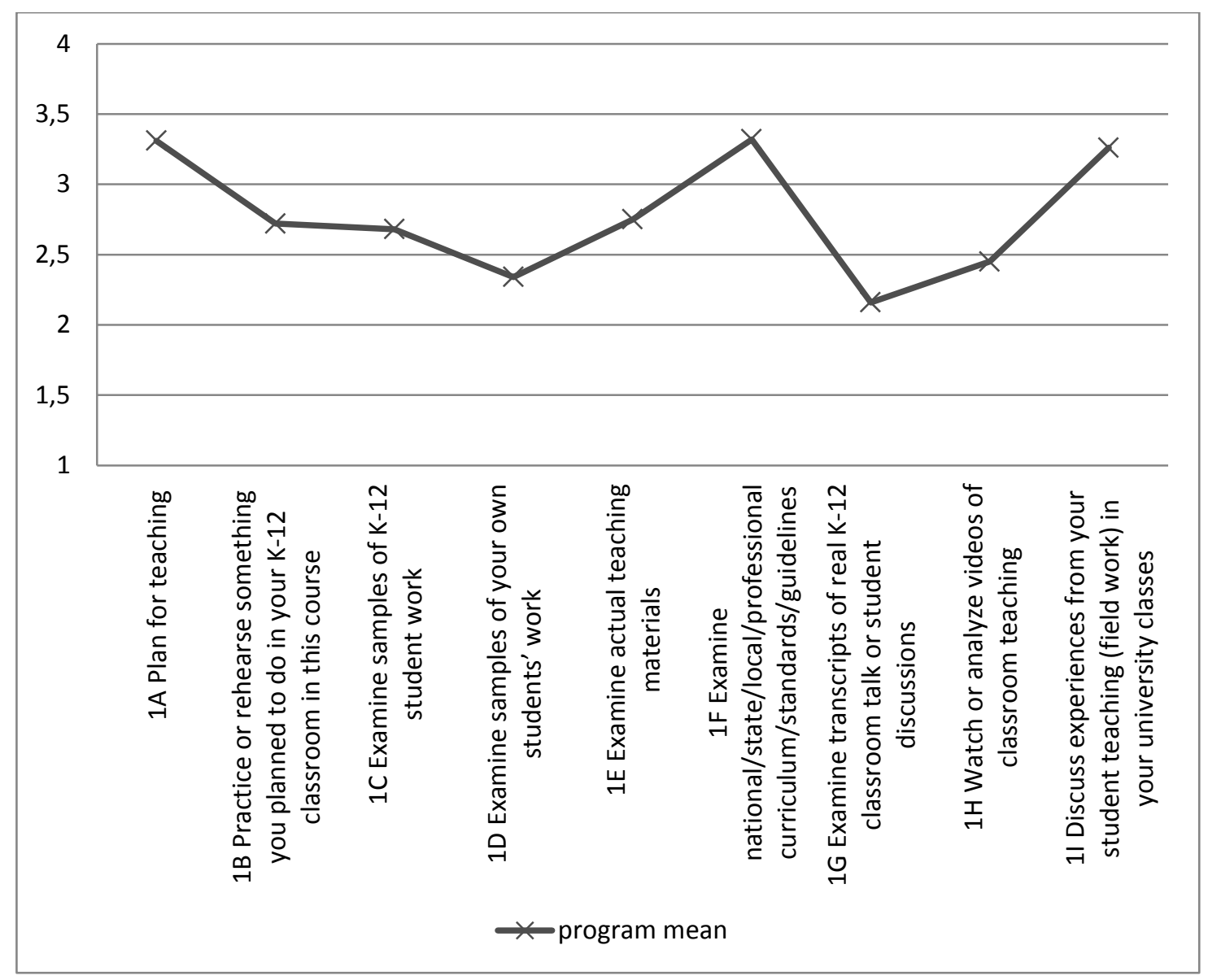

Figure 2. Mean scores across programmes per opportunity to enact practice.

To capture candidates' perceptions of their opportunities to analyse pupils' learning, we investigated the three items $1 \mathrm{C}, 1 \mathrm{G}$, and $1 \mathrm{H}$ more carefully. These items also linked to our theoretical framing, and the inclusion of the survey thus served to triangulate the observation data. The figure shows that item $1 \mathrm{D}$, referring to analysing work of the candidates' own pupils, was also rated low. Unfortunately, not all candidates in our sample had their own pupils as some programmes do not engage in concurrent practice. Therefore, we did not investigate this item more closely here.

All candidates, regardless of their subject, were asked to participate. As we encountered problems in data collection in three programmes (e.g., too small sample size or reversed items not reverse rated), the survey data we report on are from 
programmes Finland1a, Norway2a, and California3a. Both Norway2a and California3a had high response rates close to $100 \%$ as the surveys were distributed at obligatory lectures. The response rate in Finland1a was $23 \%$ due to the high flexibility of the programme which lacked obligatory classes. Nevertheless, the sample is representative in age and subject distribution.

\section{Observation}

To understand the characteristics of the candidates' opportunities to analyse pupils' learning within their campus coursework, we collected observation data. Pupils' learning is difficult to observe directly, but we wanted to capture all instances where the candidates had opportunity to see evidence of pupils' learning, in pupils' work, for instance, but also the opportunities they had to analyse pupils' learning more indirectly, by examining teachers' instructional practices for eliciting pupils' learning. Observation data were collected in all six programmes. We chose to observe the methods courses, where we believed we were most likely to see these opportunities. We selected the courses to be observed in collaboration with the local programme directors, focusing on language arts and mathematics methods courses, as these subject areas represent priorities for quality teaching in most countries (OECD 2014).

At each site, we observed for three weeks, resulting in 9 to 29 hours of observation at each programme, a total of 104 hours ${ }^{1}$. In some programmes, the same teacher educator taught all three weeks, whereas several teacher educators were

${ }^{1}$ At four of the programs, we observed about 15 hours. The remaining two programs featured two methods courses given simultaneously at the time of our observations, resulting in more hours of observations. These differences reflect, to some extent, differences in the number of class hours overall. 
observed in other programmes. The first author was responsible for collecting data at the two Norwegian sites, while four trained, local research assistants collected data at the other sites (see Hammerness \& Klette 2015, for an overview of the methodology). The observations were collected as typed, running notes. Research assistants were trained to capture as much detail as possible, for instance spoken dialogue and exact quotations, resulting in 10-15 pages of notes per observation. The detail and length of these notes enabled us to capture important interactions in the teacher education classroom. We supplemented these notes with a collection of artefacts such as assignments, PowerPoints, and candidates' work from the courses we observed.

\section{Analysis}

To investigate how candidates perceive the opportunities they have to analyse pupils' learning, we calculated the mean score of item $1 \mathrm{C}, 1 \mathrm{G}$, and $1 \mathrm{H}$ in the survey. The mean scores were calculated per program as well as for the programs combined (see Table 2). Regarding the observation data, we first categorised the candidates' opportunities to analyse pupils' learning. From our conceptual framework (see Figure 1), we included two categories for analysis, namely the candidates' opportunities to analyse: (a) K-12 pupils' work and (b) videos from classrooms. Additionally, we noticed that the candidates had opportunities to (c) analyse peers' work, and we included this as a third category for analysis. Using HyperResearch 3.5.2, we tagged every instance where candidates had any of these opportunities, regardless of time spent. Furthermore, we were interested in the scaffolding and support offered by the teacher educator, in terms of the aspects outlined in our conceptual framework: (i) to find evidence of (levels) of learning, (ii) to discover typical errors or misconceptions in pupils' reasoning, and (iii) to decide next instructional steps to help pupils learn. During our analysis, we 
discovered that the conversations were often related to (iv) subject-specific terms and concepts, so we included that as another category. Finally, the kind of (v) assignment or question posed by the teacher educator seemed important, so we also paid attention to every time an assignment or question was initiated by the teacher educators.

\section{Findings}

\section{Survey data}

Candidates perceived relatively few opportunities to analyse pupils' learning with none of the items rated above the third scale point or towards the highest score, indicating they had an extensive opportunity for such activities. Across programmes, candidates perceived they had the greatest opportunity to examine samples of K-12 pupils' work. This was followed by opportunities to watch or analyse videos of classroom teaching (see Table 2). Candidates expressed that they had the least opportunity to examine transcripts of real K-12 classroom talk or pupils' discussions.

Table 2. Mean Score per Programme per Selected Opportunity

\begin{tabular}{|l|l|l|l|}
\hline Programme & $\begin{array}{l}\text { Examine samples of } \\
\text { pupils' work }\end{array}$ & $\begin{array}{l}\text { Examine transcripts of } \\
\text { pupils' talk or } \\
\text { discussions }\end{array}$ & $\begin{array}{l}\text { Watch or analyse } \\
\text { videos of teaching }\end{array}$ \\
\hline Finland1a $(n=76)$ & $2.11(.90)$ & $1.74(.77)$ & $1.42(.62)$ \\
\hline Norway2a $(n=122)$ & $2.93(.75)$ & $2.09(.82)$ & $2.78(.80)$ \\
\hline California3a $(n=72)$ & $2.85(.82)$ & $2.72(.89)$ & $2.99(.90)$ \\
\hline Total $(n=270)$ & $2.68(.88)$ & $2.16(.90)$ & $2.45(1.01)$ \\
\hline
\end{tabular}

Note. Standard deviation in brackets. $n$ represents survey responses.

A comparison of candidates' perceptions showed that candidates from Norway2a reported to have the most opportunity to examine samples of K-12 pupils' work. On average, they expressed that they had explored this in some depth. In this case, the Norway2a candidates were closely followed by candidates from the California3a 
programme. In the case of opportunities to examine transcripts of real K-12 classroom talk or pupils' discussions and of opportunities to watch or analyse videos of classroom teaching, California3a candidates perceived to have the most opportunity and rated these opportunities above the scale mean. The candidates in the Finland1a programme expressed to have the least opportunities compared to the other candidates. They scored well below the scale mean on all three items.

\section{Observation data}

The results from the survey data were reflected in the observation data. Using our analytical framework, we only found 11 instances of analysis of pupils' learning in total across 52 lessons ( $\mathrm{N}=104$ hours). The most frequent opportunity to analyse pupils' learning observed was the opportunity to analyse actual pupils' work $(n=5)$.

Additionally, candidates had the opportunity to analyse their peers' texts $(n=3)$ and opportunities to analyse classroom videos $(\mathrm{n}=3)$. In the following, using excerpts, we present the characteristics of these opportunities.

Analysing pupils' work

The opportunities to analyse pupils' work varied substantially regarding how much time candidates were given. The following excerpt is from a language arts methods course in the Finland $1 \mathrm{~b}$ programme. The candidates had 1 hour to analyse the pupils' texts. The teacher educator gave the candidates specific instructions, asking them to look at the linguistic level. A PowerPoint slide was on display, with the heading 'linguistic quality' and bullet points highlighting specific linguistic aspects (i.e., 'vocabulary', 'nominal phrases' etc.). The candidates worked in groups for about 40 minutes before discussing in plenary: 
(1) Teacher Candidate (TC) 4: We [discussed] according to Sjöqvist's communicative quality and linguistic/content quality. Regarding the communicative quality, we think that this person clearly has the reader in mind when she writes. She says she was born in Vietnam. She writes about the events of world history so everyone knows that there has been a war in Vietnam ... then she writes that 'our country was thus destroyed with bombs' ... so she shows in few words that she has the reader in mind. It is adapted to recipient, we think. But when she writes, for example, about how many books they had at home, she does not write in the same way because that is new information for the reader. In our opinion, the text communicated with the reader and fulfilled its purpose (...)

(2) Teacher Educator (TE): What she says about childhood and?

(3) TC4: Yes, exactly, the cognitive level (...). As she writes about subjects that are both high and low in cognitive level. She writes about abstract things like this war in Vietnam and the help they received from other countries, but also on a contextual level about the books they had in their own bookshelf at home.

(4) TE: Can you clarify?

(5) TC4: Well, for instance, she writes [reads examples]. She has both abstract and concrete language and content. It is still at a relatively high cognitive level.

The candidates used subject-matter terminology, such as communicative quality (1), adaption to recipient (1), cognitive and contextual level $(3,5)$, abstract and concrete language (5), and diverse grammatical terms. This was perhaps due to the assignment that asked them specifically to look at the linguistic level, and the terminology on PowerPoint. As such, the conversation in plenary helped candidates to understand who this pupil was as a writer, and the participants elaborated on possible reasons she might have written the way she had. Still, the candidates never had opportunities to discuss the pupil's work more specifically connected to typical pupils' misconceptions or errors in this kind of work at this level, as higlighted in our analytical framework (see Figure 1).

We found other similar instances, for example in a mathematics methods course at the Norway2a programme where candidates graded pupils' exams. They had an hour to work with these exams in groups before going through them in plenary (also about 1 
hour). The candidates and the teacher educator connected their analysis specifically to mathematical concepts, saying things like 'maybe the pupil doesn't know derivation' and 'but the algebra is really horrible!' Despite these statements, the candidates were mostly comparing the scores and the breakdown of the points earned for different problems. As in the excerpt from Finland1b, they made no references to typical misconceptions the pupils' might have regarding this subject matter, nor did they discuss what the pupil might need to know to be able to develop his or her understanding (cf. Figure 1).

In both examples, the candidates had extensive time to examine the complexity in the pupils' work. They had extensive opportunity to discuss, and in the plenary conversation the candidates talked more than the teacher educator. However, on at least two occasions in our data, it was clear that the candidates were not given enough time to analyse pupils' learning in the same detail as above. One example was from a language arts methods course at Norway $2 b$, where the candidates analysed two pupils' texts in pairs. They had about 3 minutes to analyse the first text before they discussed it in plenary. They then moved on to the second text, a poem written by a pupil. On a PowerPoint slide, the teacher educator asked them to assess the language use in the poem, the principles of text organisation used, and the structure and use of paragraphs. The candidates worked in groups for a few minutes before the teacher educator interrupted, complained that they did not have more time, and opened for discussion in plenary. The discussion quickly shifted to a sequence of modelling by the teacher educator as she illustrated ways to evaluate the pupil's work:

TE: Yes, there are quite a few topic sentences there. Eventually maybe we can practice how to divide topic sentences into paragraphs. (...) We can categorise (...) time as a structuring principle. It's something you can focus on the pupils' texts. 
What structuring principle is used? I have used the text and removed all topic sentences [shows with a Word document on the projector how a teacher can move text around and make paragraphs based on the topic sentences].

Here, the candidates had little time for in-depth analysis, even though the assignment from the teacher educator was quite specific. We also note that the teacher educator did most of the talking in this situation, as she modelled how to identify topic sentences. The teacher educator continued to model other structuring principles through different tools, and as such pointed to specific subject-matter issues to look for in a pupil's text, such as topic sentences, structuring principles, and ways to make paragraphs. She did not connect this to knowledge about typical errors for this age- or pupils group, or elaborate on next steps of instruction, however. As the modelling sequence was prepared on a PowerPoint in advance, it seems that the teacher educator had planned to do this as a modelling activity. Yet, it also seems like she had wanted her candidates to work longer with the texts, which did not happen due to time constraints.

\section{Analysing peers' work}

The next excerpt is taken from a language arts methods course at California3a. The candidates had prepared assignments and rubrics, and the teacher educator asked them to form pairs. In each pair, the candidates swapped their materials so each participant solved the problems created by his or her partner and then assessed the answers using the rubrics. We observed one group of candidates while the teacher educator checked in to see how they were doing with their assignments:

(1) TE: When you're looking at the assessment, make sure that you match up the questions; this question matches with this learning objective, and so on. That's really key. (...)

(2) TC7: This assessment by TC8 is great, but my students are mostly learning English, so I could never do this. 
(3) TE: You could write that as one of your learning objectives: Students will be able to use words like 'perpendicular' or whatever. Learning objectives can relate directly to accessibility.

This excerpt does not show evidence of opportunity to look for evidence of learning, or misconceptions, or opportunity to discuss next instructional steps. Still, it is an example of analysing peers' work (cf. Figure 1), illustrating a useful pedagogy for teacher education to give candidates insight into their own or others' teaching materials from another person's perspective. Additionally, it gives information about how the design of a specific assignment and its assessment rubric could be altered to adapt to pupils' way of learning.

\section{Analysing classroom video}

The following excerpt from a language arts methods course at programme Finland1a illustrates how video was used. The teacher educator directed the candidates to an Internet site to watch a video from a secondary school classroom and asked the candidates to analyse how the teacher assessed pupils' language skills:

(1) TE: Did you pay attention to the teacher's questions? Or did you make some other observations?

(2) TC1: Well, the teacher asked follow-up questions and requested clarification in order to gain information about the pupils' vocabulary, for example.

(3) TE: Yes, and don't you think it was pretty fluent conversation? The pupil was pretty competent; she produced long turns of talk and teacher questions were designed as such that they produced long answers. And teacher questions were varying as well.

(4) TC2: To me, it appeared that this girl had been communicating a lot with native Finnish speakers, because (...) she uses this word 'niinku' [like].

(5) TC3: And 'sillee' [stuff] as well.

(6) TE: Yeah, it is informal indeed. 
The assignment was not very specific; rather, it was further specified after they had watched the video (1). One of the candidates nevertheless had a specific observation related to the teacher's questions (2), which touched upon the teacher's role in eliciting pupils' learning, but this statement was not elaborated. They also briefly discussed aspects of the pupil's performance $(3,4,5,6)$, but they did not have much time to go in depth in the analysis. As we observed when candidates were analysing pupils' and peers' work, they did not get into discussions about typical errors or how to move on with this pupil (cf. Figure 1).

\section{Discussion}

\section{Scarce opportunities to analyse pupils' learning}

Our main aim with this study was to investigate how candidates perceive their opportunities to analyse pupils' learning within their coursework on campus as well as what characterises these opportunities. Despite two data sources and extensive hours of observations, we found few opportunities to analyse pupils' learning across six programmes. This lack of attention to pupils' learning in teacher education coursework could reflect the instructional paradigm of higher education. Teaching, and teaching approaches, might have become more important than whether and how pupils learn (Barr and Tagg 1995). Teacher preparation has focused more on educating candidates how to manage pupils rather than emphasising how to create learning opportunities for pupils (Grossman, Compton et al. 2009; Windschitl et al. 2012).

Our findings might also be attributed to the traditional divide between coursework and fieldwork, where 'practical' aspects of teaching took place at the field placement site, while the university site was responsible for providing theoretical knowledge (Darling-Hammond 2006). The candidates in our sample might have 
extensive opportunities to learn theories about assessment and learning within their coursework, but they might have few opportunities to enact the practice of analysing pupils' learning. The teacher educators in our sample might expect their candidates to learn and engage in analysing pupils' learning while in their placements. In line with others (e.g., Darling-Hammond 2017; Zeichner 2010), we argue for a stronger integration and connection between the two educational sites regarding the responsibilities connected to educating candidates. Our position is supported by research showing that the opportunity to learn during field placement is not sufficient to learn ambitious teaching practices (Britzman 2003).

\section{Rigor and quality of opportunity to analyse pupils' learning}

The survey reported the extent to which the candidates perceived their opportunity to analyse pupils' learning, yet it did not tap into the specificity or quality of the opportunities offered. The observation data revealed that, when learning to analyse pupils' learning is a topic, it is treated in a detailed, specific manner. Still, the specificity was often related to recognising subject-specific concepts visible within the pupils' work (e.g., analysing a pupil's text using terms such as communicative quality and linguistic/content quality, or pointing to the use of topical sentences in the case of language arts), rather than discussing whether the work demonstrated typical errors or common misconceptions, or how to help the pupil further, as highlighted in previous research (e.g., Kazemi and Franke 2004) and included in our framework (see Figure 1). Similarly, even though studies have stressed that eliciting pupils' learning and making learning visible during teaching is important (e.g., Ritchhart et al. 2011; Windschitl et al. 2012), we have few indications in our data of candidates having or perceiving opportunities to enact or observe such practices. Our data do not include information 
about the teacher educators' purpose of the observed activities, which might also be interesting in this respect. However, investigating the effects of teacher education coursework, Clift and Brady (2005) concluded that "the impact [on candidates] is often different from what instructors or teaching supervisors may imagine or wish" (p. 331).

\section{Implications for teacher education}

Our findings suggest that teacher education programmes could pay more attention to pupils' learning at the campus site. Acknowledging that analysing pupils' learning is a complex teaching practice, we believe that providing opportunities to analyse pupils' learning allows candidates to examine the complex relationship between teaching and learning. We wonder, however, whether the full potential of these opportunities is realised. As the enactment of analysing pupils' learning is a complex practice, the pedagogy for teacher educators to convey the practice of making learning visible might inherently also be a complex one. Teacher educators must engage in deep discussions about specific instructional practices in teacher education, as called for by Ball and Cohen (1999). Our findings indicate that professional development is needed for teacher educators to be able to conduct the instructional practice of offering opportunities to analyse pupils' learning. As outlined in the theory section, the literature we reviewed suggested some specific ways to do so, and in line with Duit and Treagust $(2003,687)$ we conclude that 'the gap between what is necessary from the researcher perspective and what may be set into practice by 'normal' teachers has increased more and more'. We recommend that insights from the reviewed research on making pupils' thinking and learning visible must be implemented in teacher education to a greater extent, and feed into a pedagogy for teacher education, to improve future teachers' knowledge about how to analyse pupils' learning and build their teaching upon this learning. 
Because even though tools such as the "Tuning protocol" (Allen 1998a) do exist, there seems to be a need for tools describing instructional practices for looking at pupils' work going beyond the procedural aspects of these practices. Our study has started a discussion on the need for this specific pedagogy of teacher education, and points to existing knowledge in the research literature of specific aspects that such a pedagogy can rest upon.

Our data further indicates that practicing to analyse pupils' learning is timeconsuming. At one instance in our material, the teacher educator modelled how to analyse pupils' learning rather than letting the candidates analyse pupils' learning. Modelling is an important instructional practice in teacher education (Grossman, Hammerness, \& McDonald 2009), and modelling these complex practices of analysing pupils' learning might be an efficient instructional practice in teacher education. Nevertheless, scholars have also pointed to the importance for candidates to have opportunities to rehearse and enact these teaching practices themselves within their coursework (Kennedy 1999).

\section{Limitations and further research}

Our research is based upon six teacher education programmes. Further research is needed to obtain more knowledge about the status of opportunities to analyse pupils' learning across other programmes before concluding that this is in fact underemphasised in teacher education. A longitudinal and experimental design could be a valuable addition to the existing body of knowledge. Further, three weeks is a limited period of observations that reports on a slice of the opportunities to learn provided in the programmes. Based on classroom studies indicating that four consecutive lessons per classroom suffice to get a first overview of patterns of teaching (e.g., Ball and Hill 
2009), we estimated that, for our purposes, three weeks would be sufficient. Although a longer period of observation might have given us more certainty, the triangulation with survey data adds strength to our findings. Nevertheless, further research should provide more knowledge about the instructional practices within teacher education coursework specifically targeting pupils' learning, and the use of video data might be an advantage in continuing this work.

We have suggested that programmes look at research literature for ways to enhance the instructional practices linked to opportunities to analyse pupils' learning. Yet, it is an empirical question whether such instructional practices will lead to better teachers and, in the long run, better learning for their pupils. Diez (2010) reminded us that knowing the impact of teacher education on pupils' learning is complicated. She emphasised that not only are there uncertainties connected to whether the candidates learn what the programme teaches them, but also if they are practicing what they have learned, and if that practice does indeed result in pupils' learning. More studies should investigate this flow of impact on pupils' learning. 


\section{References}

Allen D., Ort, S. W., and Schmidt, J. 2009. "Supporting classroom assessment practice: Lessons from a small high school”, Theory Into Practice, 48 (1): 72-80, doi: $10.1080 / 00405840802577650$

Allen, D. 1998a. “The tuning protocol: Opening up for reflection”. In Assessing student learning: From grading to understanding, edited by D. Allen, 87-104. New York: Teachers College Press.

Allen, D., ed. 1998b. Assessing student learning: From grading to understanding. New York: Teachers College Press.

Allen, D., and Blythe, T. 2004. The facilitator's book of questions: Tools for looking together at student and teacher work. New York: Teachers CollegePress.

Ball, D. L., and D. K. Cohen. 1999. "Developing Practice, Developing Practitioners: Toward a Practice-Based Theory of Professional Education." In Teaching as the Learning Profession: Handbook of Policy and Practice, edited by G. Sykes and L. Darling-Hammond, 3-32. San Francisco, CA: Jossey Bass.

Ball, D. L., and H. C. Hill. 2009. "Measuring Teacher Quality in Practice.” In Measurement Issues and Assessment for Teaching Quality, edited by D. H. Gitomer, 80-98. Thousand Oaks, CA: Sage Publications.

Barr, R. B., and J. Tagg. 1995. "From Teaching to Learning — A New Paradigm for Undergraduate Education." Change: The Magazine of Higher Learning 27 (6): 12-26. doi:10.1080/00091383.1995.10544672.

Blömeke, S., Gustafsson, J.-E., and Shavelson, R. 2015. "Beyond dichotomies: 
Competence viewed as a continuum". Zeitschrift für Psychologie, 223, 3-13. http://dx.doi.org/10.1027/2151-2604/a000194

Blythe, T., Allen, D., and Powell, B. S. 2008. Looking together at student work. New York: Teachers College Press.

Boyd, D. J., P. L. Grossman, H. Lankford, S. Loeb, and J. Wyckoff. 2009. “Teacher Preparation and Student Achievement”. Educational Evaluation and Policy Analysis 31 (4): 416-440. doi:10.3102/0162373709353129.

Britzman, D. 2003. Practice Makes Practice: A Critical Study of Learning to Teach. Albany: State University of New York Press.

Bruner, J. S. 2010. Beyond the information given: Studies in the psychology of knowing. Abingdon: Routledge.

Canrinus, E. T., Bergem, O. K., Klette, K., \& Hammerness, K. Under review. Opportunities to enact practice in campus courses: Taking a student perspective. Teachers and Teaching Theory and Practice.

Chaiklin, S., and J. Lave. 1993. Understanding practice: Perspectives on activity and context. Cambridge, England: Cambridge University Press

Clift, R. T., and P. Brady. (2005). "Research on methods courses and field experiences". In M. Cochran- Smith \& K. Zeichner (Eds.), Studying teacher education. the report of the AERA panel on research and teacher education (pp. 309-424). Mahwah, NJ: Lawrence Erlbaum Associates.

Cushman, K. 1996. Looking collaboratively at student work: An essential toolkit [Whole issue]. Horace, 13 (2). Avaliable from Coalition of Essential Schools. 
Darling-Hammond, L. 2006. Powerful teacher education: Lessons from exemplary programmes. San Francisco, CA: Jossey-Bass.

Darling-Hammond, L. 2017. "Teacher Education Around the World: What Can We Learn from International Practice?" European Journal of Teacher Education 40 (3): 291-309. doi:10.1080/02619768.2017.1315399.

Darling-Hammond, L., Bransford, J., LePage, P., Hammerness, K., Duffy, H., DarlingHammond, L., . . Duffy, H. (2005). Preparing teachers for a changing world: What teachers should learn and be able to do. San Francisco, CA: Jossey-Bass.

Diez, M. E. 2010. “It Is Complicated: Unpacking the Flow of Teacher Education's Impact on Student Learning.” Journal of Teacher Education 61 (5): 441-450. doi:10.1177/0022487110372927.

Driver, R. 1989. “Students' Conceptions and the Learning of Science.” International Journal of Science Education 11 (5): 481-490. doi:10.1080/0950069890110501.

Duit, R., and D. F. Treagust. 2003. "Conceptual Change: A Powerful Framework for Improving Science Teaching and Learning." International Journal of Science Education 25 (6): 671-688. doi:10.1080/09500690305016.

Eisenhardt, K. M., and M. E. Graebner. 2007. Theory building from cases: Opportunities and challenges. The Academy of Management Journal, 50(1), 2532. doi:10.5465/AMJ.2007.24160888

Engelien, K., T. Eriksen, and R. Jakhelln. 2015. "Integrerte studiedesign for femårig lærerutdanning” [Integrated Study Design for Five-Year Teacher Education]. In Veier til fremragende larerutdanning [Roads Towards Excellent Teacher 
Education], edited by U. Rindal, A. Lund, and R. Jakhelln, 157-169. Oslo, Norway: Universitetsforlaget.

Grossman, P., C. Compton, D. Igra, M. Ronfeldt, E. Shahan, and P. Williamson. 2009. “Teaching Practice: A Cross-Professional Perspective.” Teachers College Record 111 (9): 2055-2100.

https://cset.stanford.edu/sites/default/files/files/documents/publications/Grossma n-TeachingPracticeACross-ProfessionalPerspective.pdf.

Grossman, P., Hammerness, K., \& McDonald, M. A. (2009). Redefining teaching, reimagining teacher education. Teachers and teaching: Theory and practice, 15(2), 273-290.

Gaudin, C., and S. Chaliès. 2015. "Video Viewing in Teacher Education and Professional Development: A Literature Review.” Educational Research Review 16: 41-67. doi:http://dx.doi.org/10.1016/j.edurev.2015.06.001.

Hammerness, K. (2006). From Coherence in Theory to Coherence in Practice. Teachers College Record, 108(7), 1241-1265.

Hammerness, K., \& Klette, K. (2015). Indicators of quality in teacher education: Looking at features of teacher education from an international perspective. In A. W. Wiseman \& G. K. LeTendre (Eds.), Promoting and sustaining a quality teaching workforce (Vol. 27, pp. 239-277). Bingley, England: Emerald Group Publishing.

Hatch, T., and P. Grossman. 2009. "Learning to Look Beyond the Boundaries of Representation: Using Technology to Examine Teaching (Overview for a Digital Exhibition: Learning from the Practice of Teaching)." Journal of Teacher 
Education 60 (1): 70-85. doi:10.1177/0022487108328533.

Hattie, J., and H. S. Timperley. 2007. "The Power of Feedback.” Review of Educational Research 77 (1): 81-112. doi:10.3102/003465430298487.

Hiebert, J., A. K. Morris, D. Berk, and A. Jansen. 2007. Preparing teachers to learn from teaching. Journal of Teacher Education, 58(1), 47-61. doi:10.1177/0022487106295726

Kazemi, E., and M. L. Franke. 2004. “Teacher Learning in Mathematics: Using Student Work to Promote Collective Inquiry." Journal of Mathematics Teacher Education 7 (3): 203-235. doi:10.1023/B:JMTE.0000033084.26326.19.

Kennedy, M. 1999. “The Role of Pre-Service Teacher Education.” In Teaching as the Learning Profession: Handbook of Teaching and Policy, edited by L. DarlingHammond and G. Sykes, 54-86. San Francisco, CA: Jossey Bass.

Lampert, M., M. L. Franke, E. Kazemi, H. Ghousseini, A. C. Turrou, H. Beasley, . . K. Crowe. 2013. Keeping it complex: Using rehearsals to support novice teacher learning of ambitious teaching. Journal of Teacher Education, 64(3), 226-243. doi:10.1177/0022487112473837

Little, J. W. 2004. “'Looking at Student Work' in the United States: Countervailing Impulses in Professional Development." In International Handbook on the Continuing Professional Development of Teachers, edited by C. Day and J. Sachs, 94-118. Maidenhead, UK: Open University Press.

Little, J. W., M. Gearhart, M. Curry, and J. Kafka. 2003. "Looking at Student Work for Teacher Learning, Teacher Community, and School Reform.” Phi Delta Kappan 
85 (3): 184-192. doi:10.1177/003172170308500305.

Maulana, R., M. Helms-Lorenz, and W. van de Grift. 2015. "Development and Evaluation of a Questionnaire Measuring Pre-Service Teachers' Teaching Behaviour: A Rasch Modelling Approach.” School Effectiveness and School Improvement 26 (2): 169-194. doi:10.1080/09243453.2014.939198.

McDonald, J. P., N. Mohr, A. Dichter, and E. C. McDonald. 2013. The power of protocols: An educator's guide to better practice. 3rd ed. New York: Teachers college press.

Mercer, N., and L. Dawes. 2014. "The Study of Talk Between Teachers and Students, from the 1970s until the 2010s." Oxford Review of Education 40 (4): 430-445. doi:10.1080/03054985.2014.934087.

Munthe, E., K.-A. S. Malmo, and M. Rogne. 2011. "Teacher Education Reform and Challenges in Norway." Journal of Education for Teaching 37 (4): 441-450. doi:10.1080/02607476.2011.611012.

Niemi, H., and R. Jakku-Sihvonen. 2006. “Research-based Teacher Education.” In Research Based Teacher Education in Finland: Reflections by Finnish Teacher Educators, edited by R. Jakku-Sihvonen and H. Niemi, 31-47. Turku, Finland: Finnish Educational Research Association.

NOKUT (Norwegian Agency for Quality Assurance in Education). 2006. Evaluering av allmennlarerutdanningen i Norge 2006. Del 1: Hovedrapport [Evaluation of General Teacher Education in Norway 2006. Part 1: Main Report]. http://www.nokut.no/Documents/NOKUT/Artikkelbibliotek/Norsk_utdanning/E valuering/alueva/ALUEVA_Hovedrapport.pdf. 
OECD (Organisation for Economic Co-operation and Development). 2014. PISA 2012 Results: What Students Know and Can Do - Student Performance in Mathematics, Reading and Science (Volume I, Revised edition, February 2014), PISA, OECD Publishing. doi:10.1787/9789264201118

Ritchhart, R., M. Church, and K. Morrison. 2011. Making Thinking Visible: How to Promote Engagement, Understanding and Independence for All Learners. San Francisco, CA: Jossey-Bass.

Sahlberg, P. 2011. Finnish Lessons: What Can the World Learn from Educational Change in Finland? New York, NY: Teachers College Press.

Seidel, T., and K. Stürmer. 2014. "Modeling and Measuring the Structure of Professional Vision in Preservice Teachers.” American Educational Research Journal 51 (4): 739-771. doi:10.3102/0002831214531321.

Shepard, L., Hammerness, K., Darling-Hammond, L., Rust, F., Snowden, J. B., Gordon, E., .. . Pacheco, A. (2005). Assesment. In L. Darling-Hammond \& J. Bransford (Eds.), Preparing teachers for a changing world: What teachers should learn and be able to do (pp. 275-326). San Francisco, CA: Jossey-Bass.

Sherin, M. G., Jacobs, V. R., and Philipp, R. A. 2010. Mathematics teacher noticing: Seeing through teachers' eyes. New York: Routledge.

Shulman, L. S. 1986. "Those who understand: Knowledge growth in teaching”. Educational Researcher, 15(2), 4-14. doi:10.3102/0013189x015002004

Shulman, L. S. 1987. "Knowledge and teaching: Foundations of the new reform". Harvard Educational Review, 57(1), 1-22. doi:10.17763/haer.57.1.j463w79r56455411 
Sloan, T. F. 2015. "Data and Learning that Affords Program Improvement: A Response to the U.S. Accountability Movement in Teacher Education." Educational Research for Policy and Practice 14 (3): 259-271. doi:10.1007/s10671-0159179-y.

Stake, R. E. 2006. Multiple Case Study Analysis. New York, NY: Guilford Press.

Star, J. R., and S. K. Strickland. 2008. "Learning to Observe: Using Video to Improve Preservice Mathematics Teachers' Ability to Notice.” Journal of Mathematics Teacher Education 11 (2): 107-125. doi:10.1007/s10857-007-9063-7

van Es, E. A., and M. G. Sherin. 2002. "Learning to Notice: Scaffolding New Teachers' Interpretations of Classroom Interactions.” Journal of Technology and Teacher Education 10 (4): 571-596.

https://www.researchgate.net/publication/252692170_Learning_to_Notice_Scaff olding_New_Teachers'_Interpretations_of_Classroom_Interactions.

van Es, E. A., and Sherin, M. G. 2008. 'Mathematics teachers' 'learning to notice' in the context of a video club". Teaching and Teacher Education, 24(2), 244-276. doi:10.1016/j.tate.2006.11.005

Wiliam, D. 2010. The Role of Formative Assessment in Effective Learning Environments. Paris, France: OECD Publishing.

Windschitl, M., J. Thompson, M. Braaten, and D. Stroupe. 2012. "Proposing a Core Set of Instructional Practices and Tools for Teachers of Science." Science Education 96 (5): 878-903. doi:10.1002/sce.21027.

Wæge, K., and O. K. Haugaløkken. 2013. "Research-based and Hands-on Practical Teacher Education: An Attempt to Combine the Two." Journal of Education for 
Teaching 39 (2): 235-249. doi:10.1080/02607476.2013.765195.

Zeichner, K. M. 2016. "The Changing Role of Universities in US Teacher Education." In Do Universities Have a Role in the Education and Training of Teachers? An International Analysis of Policy and Practice, edited by B. Moon, 107-126. Cambridge, England: Cambridge University Press.

Zeichner, K. M. 2010. "Rethinking the Connections Between Campus Courses and Field Experiences in College- and University-based Teacher Education.” Journal of Teacher Education 61 (1-2): 89-99.

doi:10.1177/0022487109347671. 